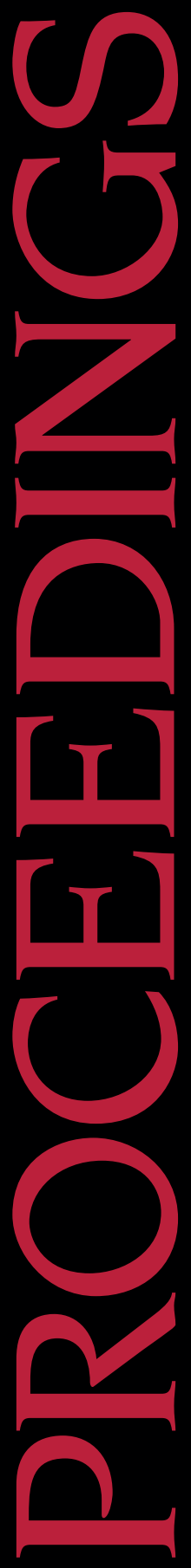

(1) American Society of International Law

\section{Proceedings of the 11lth}

\section{Annual Meeting}

\section{What International Law Values}

\section{American Society of International Law}

April 12-15, 2017

Washington, DC 


\section{Proceedings of the 111 th Annual Meeting \\ What International Law Values \\ April 12-15, 2017 \\ Washington, DC}

Proceedings of the ASIL Annual Meeting (Proceedings) is the official record of the American Society of International Law's Annual Meeting. It documents the array of presentations, addresses and discussions among scholars, practitioners, judges, government officials, and advocates from around the world who meet each year to discuss the most salient international legal issues of the day. For over a century, the Annual Meeting has been among the most important gatherings of international law professionals, bringing together more than 1,200 participants from some 75 countries. Proceedings serves as an indispensable account of the state of international law throughout the world.

Proceedings does not accept unsolicited submissions. Each Volume documents the year's Annual Meeting. Shortly after each Meeting, presenters are invited to submit a written version of their presentation by a particular deadline.

It is the policy of the American Society of International Law not to take an official position, by resolution or otherwise, upon controversial questions. The views expressed in the addresses, remarks, and discussions delivered at the ASIL Annual Meeting and appearing in Proceedings are those of the individual speakers and are not to be taken as representing the views of the Society.

\section{The American Society of InTERnational LaW}

The American Society of International Law (ASIL) is a nonprofit, nonpartisan, educational membership organization founded in 1906 by U.S. Secretary of State Elihu Root and chartered by Congress in 1950. Headquartered in Washington, D.C., its mission is "to foster the study of international law and to promote the establishment and maintenance of international relations on the basis of law and justice." ASIL holds Special Consultative Status with the Economic and Social Council of the United Nations and is a constituent society of the American Council of Learned Societies.

ASIL's nearly four thousand members hail from more than one hundred nations with nearly 40 percent residing outside the United States. Its members include scholars, jurists, practitioners, government officials, leaders in international and nongovernmental organizations, students, and others interested in international law. Through its many publications, conferences, briefings, and educational events, ASIL seeks to serve the needs of its diverse membership and to advance understanding of international law among policymakers and the public.

ASIL is a volunteer-led organization governed by a sixty-member Executive Council elected by its membership. In partnership with the elected leadership, ASIL is led by an executive director and supported by a professional staff.

\section{Become a Member \\ asil.org/membership}

Join one of the Society's Partner Programs and Receive Complimentary Ad Space in Proceedings asil.org/financial-support/sponsors-and-institutional-supporters

\section{Follow the Society on Twitter}

twitter.com/asilorg

Like us on Facebook

facebook.com/AmericanSocietyofInternationalLaw 


\section{JOURNAL INFORMATION}

Proceedings is published annually in print and online by Cambridge University Press on behalf of the American Society of International Law. To reduce time between acceptance and publication, contributions may appear online as FirstView publications in advance of their scheduled publication in an issue. Discover the entire Proceedings back archive at cambridge.org/core/journals/proceedings-of-the-asilannual-meeting/all-issues

\section{Subscriptions}

The electronic version of Proceedings is available to all members of the American Society of International Law by login to the ASIL website www.asil.org. Print copies are available to members for an additional fee.

To subscribe as a non-member or recommend a subscription to your librarian go to cambridge.org/ core/journals/proceedings-of-the-asil-annual-meeting.

\section{Claims and Address Updates}

subscriptions_newyork@cambridge.org (in the USA, Canada and Mexico) journals@cambridge.org (elsewhere)

\section{Copyright and Permissions}

cambridge.org/about-us/rights-permissions.

To Advertise in the Journal

ad_sales@cambridge.org

\section{Abstracting and Indexing Services}

cambridge.org/core/journals/proceedings-of-the-asil-annual-meeting/information/abstractingindexing-services

\section{For Other ASIL Publications}

www.asil.org

\section{Proper Citation}

Proceedings shall be cited according to the following example:

111 ASIL PRoc. 214 (2017)

ISSN: 0272-5037

E-ISSN: 2169-1118

(C) American Society of International Law 


\section{PROCEEDINGS OF THE 111TH ANNUAL MEETING}

Chairs of the Committee

of the Annual Meeting

Aloysius Llamzon

Julie Maupin

Saira Mohamed
Co-Editors of the Proceedings

Aloysius Llamzon

Julie Maupin

Saira Mohamed

\section{Contents}

Foreword ix

An Introduction: What International Law Values

Aloysius Llamzon, Julie Maupin, and Saira Mohamed 1

Nineteenth Annual Grotius Lecture

Civil War Time: From Grotius to the Global War on Terror

David Armitage 3

On the Civil-Ness of Civil War: A Comment on David Armitage's Civil War Time Mary L. Dudziak

International Law and the Trump Administration: National and International

Security

Opening Remarks by:

Lucinda Low 21

Introductory Remarks by:

Oonagh Fitzerald

Benjamin Wittes

Remarks by:

Shireen Hunter

John Bellinger

Elisa Massimino

Balancing Rights and Obligations of States and Investors

Introductory Remarks by:

R. Doak Bishop

Balancing Rights and Obligations of States and Investors: Is Reform Real or Imagined?

Donald McRae 44

Rebalancing Rights and Duties of States and Investors Marcos Orellana

Heading Off Disputes by Paying Attention to Human Rights in Foreign Investor/Host State Contract Negotiations John F. Sherman III

Protecting Human Rights and Preserving the Benefits of ISDR Hewitt Pate

Changes in the Balance of Rights and Obligations: Toward Investor Responsibilization 
International Law and Cyberspace: Challenges for and by Non-State Actors

Introductory Remarks by:

Laura Dickinson

Remarks by:

Col. Gary Corn 57

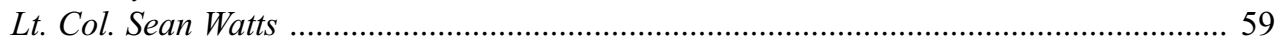

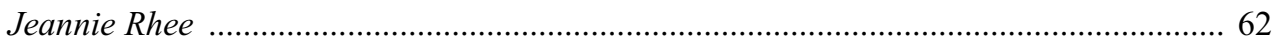

How International is International Law?

Remarks by:

Lori F. Damrosch

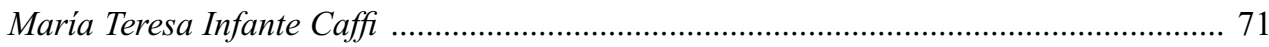

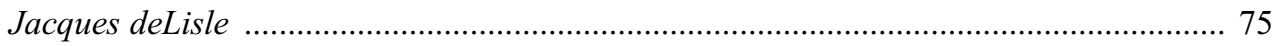

The Right to Fair Trials Under International Law

Remarks by:

Mark Ellis

TPP, Brexit, and After: The Uneasy Future of Deep Economic Agreements

WTO Procedures to Monitor RTAs

Rohini Acharya

Foreign Policy and Trade Law: Japan's Unexpected Leadership in TPP

Negotiations

Christina L. Davis

Stocktaking and Glimpsing at Trade Law's Next Generation

Kathleen Claussen

Are International Claims Commissions Effective Dispute Resolution

Mechanisms?

Introductory Remarks by:

Natalie Klein 97

Remarks by:

John R. Crook

Crafting a Successful International Mass Claims Commission

Chiara Giorgetti

The Future of International Claims Commissions: Conceptualizing the EU'S

Proposed Multilateral Investment Court as an International Claims Tribunal

Jeremy K. Sharpe

Does International Law Value Regionalism in Criminal Law Enforcement?

Introductory Remarks by:

Erika de Wet

The Shared Goals but Distinct Roles of Criminal and Human Rights Courts

Alexandra Huneeus

Late Breaking Panel: Missile Strikes Against Syria

Introductory Remarks by:

Catherine Powell

Remarks by:

Harold Hongju Koh

President Trump's Declaration of War Against Syria

Saikrishna Bangalore Prakash 
Remarks by:

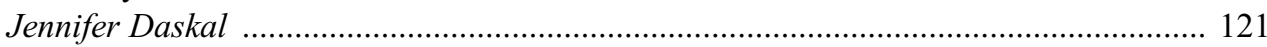

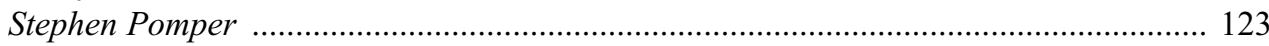

Debate: Compulsory Jurisdiction in International Dispute Settlement: Beyond

David Versus Goliath?

Introduction

Remarks by:

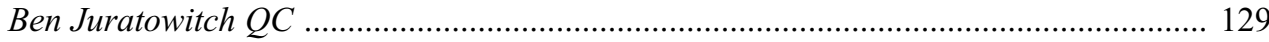

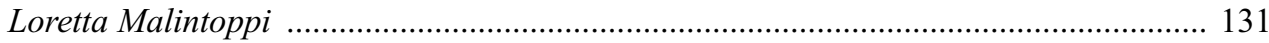

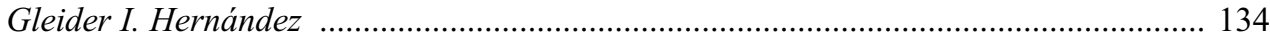

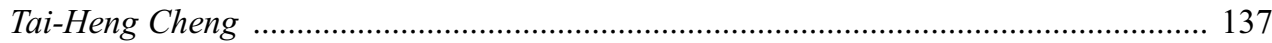

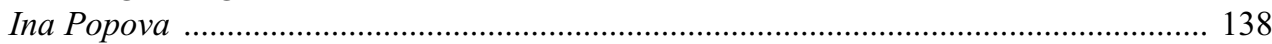

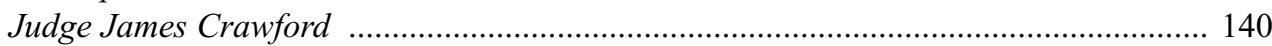

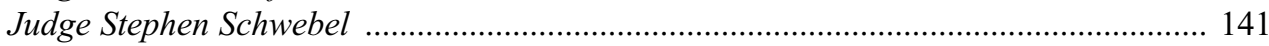

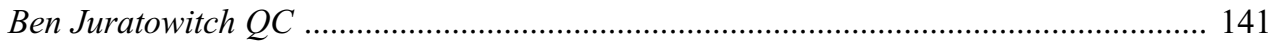

Arms Control and The Challenges of New Technologies

Cyber Defense Norms and NATO

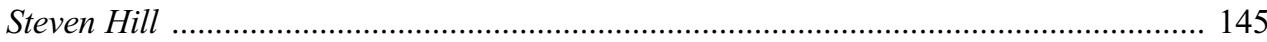

Keynote Address

Philippe Sands $Q C$

International Law and The Trump Administration: Trade and Investment

Opening Remarks by:

Mark Agrast

Remarks by:

Oonagh Fitzgerald

Introductory Remarks by:

Gary Hufbauer

Remarks by:

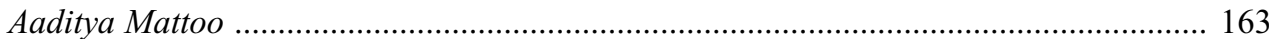

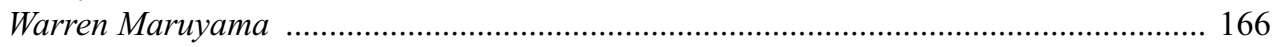

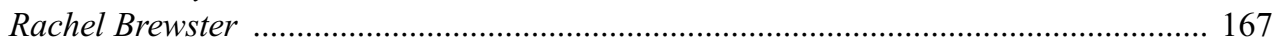

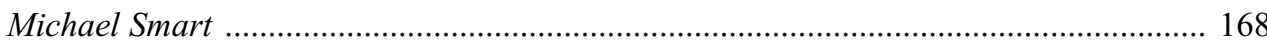

Vagts Roundtable: Lawyering in The Age of Transnational Government

Opening Remarks by:

Lucinda Low

Remarks by:

Karen Vagts

Introductory Remarks by:

Hannah Buxbaum

Remarks by:

Kath Hall

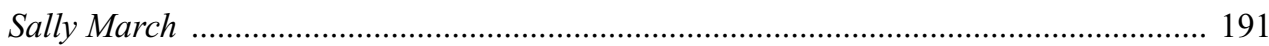

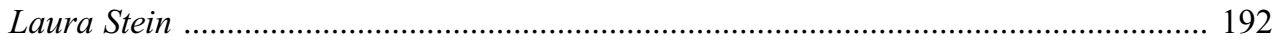

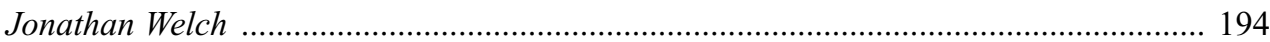

The Rise of Multistakeholder Global Governance

The Rise of Multistakeholder Partnerships

Ayelet Berman 
Hudson Medal Luncheon: A Conversation With Georges Abi-Saab

Opening Remarks by:

Lucinda Low

Remarks by:

Paul Reichler

Introductory Remarks by:

Philip Alston

Remarks by:

Georges Abi-Saab

Military Intervention by Consent

Remarks by:

Ashley S. Deeks

Consent, Forcible Intervention, and Internal Justification to Use Force

Eliav Lieblich

Military Intervention by Consent and Its Relationship to International Human Rights Law

Jonathan Horowitz

Remarks by:

Robert Taylor

Fifth Annual Charles N. Brower Lecture on International Dispute Resolution:

The Multiple Functions of International Courts and the Singular Task of the

Adjudicator

Remarks By:

David D. Caron

Regulating the Global Commons: The BBNJ Negotiations and Ocean Spaces

Beyond National Jurisdiction

Introductory Remarks by:

Catherine Redgwell

Capacity Building and Technology Transfer for Marine Biodiversity in Areas

Beyond National Jurisdiction

Harriet Harden-Davies

Marine Genetic Resources, Including Sharing of Benefits Angel Horna

Area-Based Management Tools, Including Marine Protected Areas

Penelope Nevill

Environmental Assessment in Marine Areas Beyond National Jurisdiction:

Practice and Prospects

Robin Warner

The Inter-American Human Rights System: Latest Jurisprudential Advances and Setbacks

Remarks by:

Thomas Antkowiak

Women's Rights in Recent Inter-American Human Rights Jurisprudence Bernard Duhaime

Remedies of the Inter-American Human Rights System

Viviana Krsticevic

Remarks by:

Alejandra Gonza 
Friday Keynote: Seen and not Heard

Sandie Okoro

International Law and the Trump Administration: Global Engagement on

Environmental Law

Opening Remarks by:

Lucinda Low

Remarks by:

Sylvia Maciunas

Introductory Remarks by:

Paul Joffe

Remarks by:

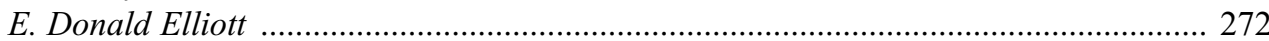

Susan Casey-Lefkowitz ............................................................................................ 275

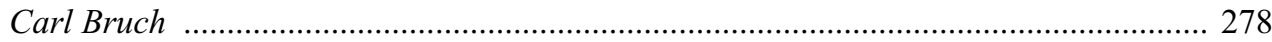

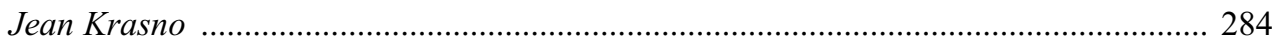

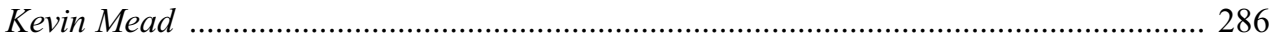

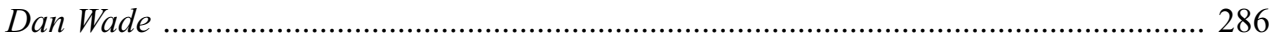

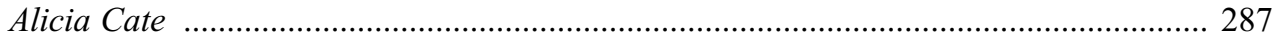

Valuing Women in International Adjudication

Introductory Remarks by:

Susan Franck

Valuing Women as Counsel in International Adjudication

Kate Parlett

Valuing Diversity in All Forms in International Courts

Josephine Jarpa Dawuni

The Value and Purpose of International Law

The Purpose of International Law Is to Advance Justice- and International Law

Has No Value Unless It Does So

Mortimer N.S. Sellers

Remarks by:

Maxwell Chibundu

Peace is the Fundamental Value that International Law Exists to Serve

Cecilia M. Bailliet

New Voices: Jurisdictional Issues in International Law

Rethinking Compulsory Jurisdiction: The Case for U.S. Reentry into the ICJ'S

Optional Clause System

Brian McGarry

Jurisdiction over Incidental Questions in International Law

Ben Love

Designing Transnational Litigation: The Case Against Forum Non Conveniens

Maggie Gardner

Closing Plenary: Building Trust in International Law and Institutions

Opening Remarks by:

Lucinda Low

Introductory Remarks by:

Ernst Hirsch Ballin

Remarks by:

Christine van den Wyngaert 


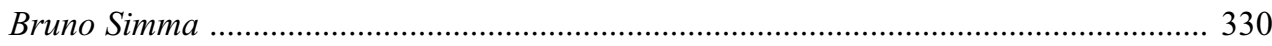

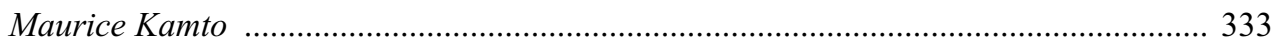

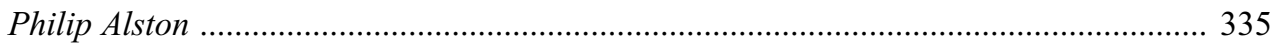

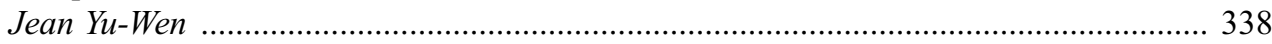

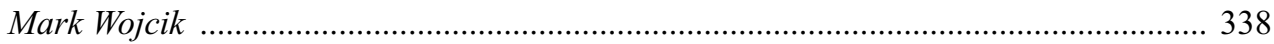

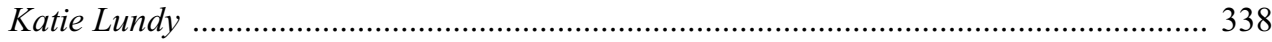

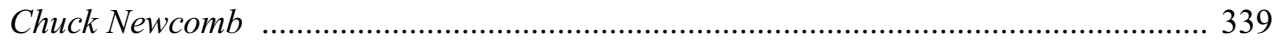

Saskia Bruines .................................................................................................. 342

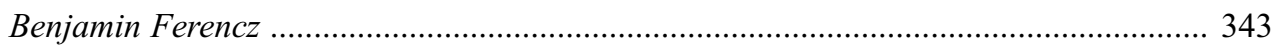

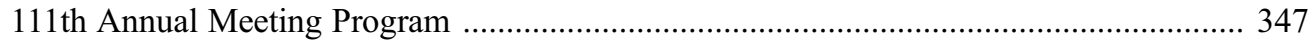

ASIL 2017 Annual Meeting Daily Program ....................................................................... 349

Fifty-Eighth Annual Philip C. Jessup International Law Moot Court Competition ........... 379

\section{Appendices}

ASIL Assembly and Annual General Meeting ……........................................................ 385

\section{In Memoriam}

Sir Elihu Lauterpacht (1928-2017)

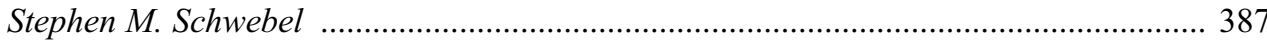

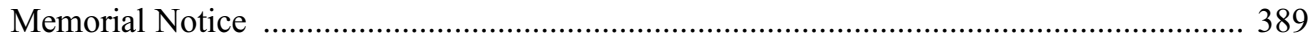

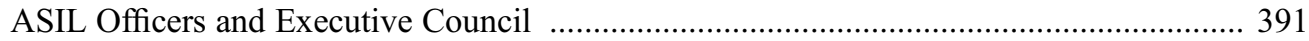

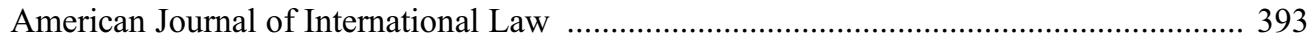

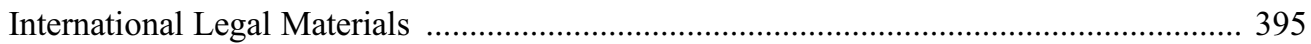

